\title{
Neogene Achlada lignite deposits in NW Greece
}

\author{
IOANNIS OIKONOMOPOULOS, GEORGIOS KAOURAS, PRODROMOS ANTONIADIS, THEOdORA \\ PERRAKI \& HANS-JOACHIM GREGOR
}

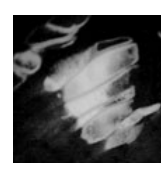

\begin{abstract}
Preliminary macro-petrographical analyses of samples taken from late Miocene (Pontian) to early Pliocene/Pleistocene lignite deposits at Achlada, northwestern Greece, show that there are two units in the lower $10 \mathrm{~m}$ of the lignite-bearing sequence. From 0 to $3.20 \mathrm{~m}$ a mixed xylite-rich /matrix lithotype is dominant and from 3.20 to $10 \mathrm{~m}$ a matrix-dominated lithotype is prevalent. The layers consist of organic and inorganic cyclical alternations with intercalated typical xylite horizons. The first results of coal petrographic analyses indicate a predominant huminite maceral group (60-81\%) with a high content in liptinite (4-10\%), and low in inertinite (0.2-2\%). Plant association types revealed from palynological and seed and fruit analyses are open water, reedmoor, Taxodiaceae forest and mixed forest environments. Mineralogical research using X-ray diffraction (XRD), thermo-gravimetric (TG/DTG), differential thermal analysis (DTA), and Fourier Transform Infra Red (FT-IR) spectroscopy, shows that clay minerals prevail in all samples, with illite-muscovite being the dominant phase, followed by kaolinite and chlorite but with no smectite. The general area was a floodplain environment which included a large meandering river system. - Key words: Neogene, Pliocene, lignite, xylite, palaeoclimatology, palaeoenvironment, Greece.
\end{abstract}

Oikonomopoulos, I., KaOuras, G., Antoniadis, P., PerraKi, T. \& GREGor, H.-J. 2008. Neogene Achlada lignite deposits in NW Greece. Bulletin of Geosciences 83(3), 335-338 (9 figures, 2 tables). Czech Geological Survey, Prague. ISSN 1214-1119. Manuscript received May 23, 2007; accepted in revised form January 16, 2008; issued September 30, 2008.

Ioannis Oikonomopoulos, Georgios Kaouras, Prodromos Antoniadis \& Theodora Perraki, National Technical University of Athens, Department of Mining Engineering, 9 Iroon Polytechniou Street, 15773 Athens, Greece; giannis@metal.ntua.gr,antoniad@metal.ntua.gr,peraki@metal.ntua.gr・Hans-Joachim Gregor, Palaeo-Bavarian Geological Survey, Daxer str.21,D-82140 Olching, Germany; H.-J.Gregor@t-online.de

The Greek peninsula is an area where vivid neotectonic activity takes place and many lignite deposits are located. During the period from the Neogene to the Quaternary, a large number of major and minor faults developed and sections of crystalline basement rocks were depressed, causing the development of isolated littoral or intramontain basins. In the shallow waters of these basins, plant debris from the surrounds accumulated and formed the most important lignite deposits in Greece, such as Florina, Ptolemais, Megalopolis and Drama (Koukouzas \& Koukouzas 1995). These deposits are of great interest because of their abundance and economic value, as they provide the main source of raw material needed for electricity production. Consequently, much research has already been carried out concerning these Greek lignite deposits (Kaouras 1989, Loh 1992, Riegel et al. 1995, Antoniadis \& Gregor 1996, Georgakopoulos \& Valceva 2000, Papanicolaou et al. 2000, Kalaitzidis et $a l .2004)$. In addition, Tertiary lignite sequences in general provide exceptional opportunities for continuous examination of the environmental change that happened during their formation.
Cooperation between the National Technical University of Athens (N.T.U.A) and the University of Cologne have led to combined research regarding the genesis and evolution of the Greek lignite deposits. Examination of facies succession in each individual lignite deposit, the representation of ecosystems that participated in the lignite formation, a comparison of past and recent environments and finally their relationship to the dynamic of each individual lignitiferous (lignite-bearing) basin have all been studied. The early stages of research included research on individual lignite deposits at the eastern margins of the Florina Sub-basin (e.g., Blachou 1999, Bali 2005, Ilia 2007). However, individual lignite deposits at Achlada have not yet been studied in detail. Kalaitzidis et al. (2003) highlighted the presence of leonardite in the Achlada coal seams and Antoniadis et al. (2001) focused on coal petrography. The latter characterized the deposits as huminitic type lignites that had been formed in a telmatic environment mainly under mesotrophic to rheotrophic hydrological conditions. Moreover, Zeppos et al. (1993) researched the total lignite deposits, which are present at the eastern margins of the Florina Sub-basin, giving emphasis to the financial potential. 

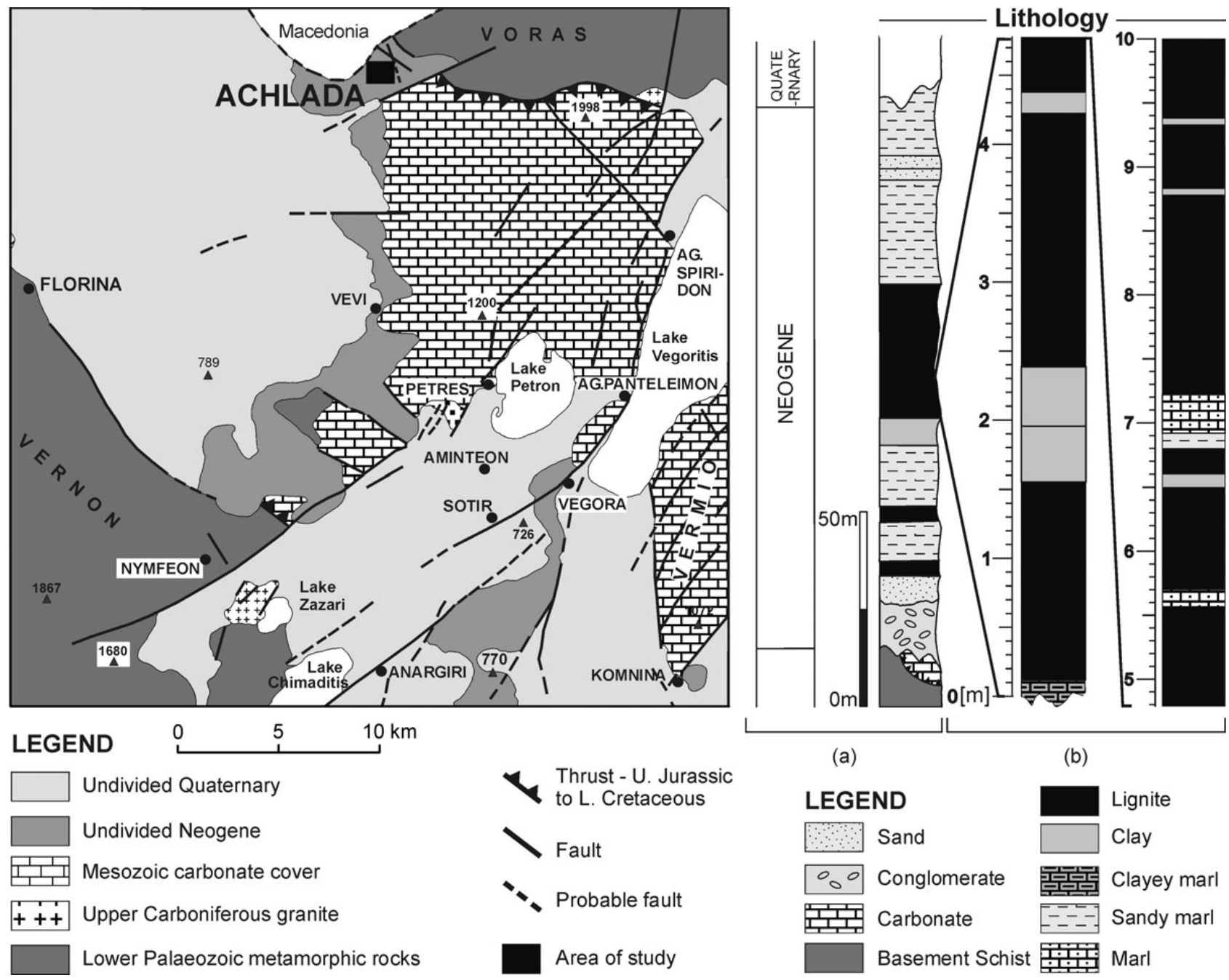

Figure 1. Geological map of the Florina Basin with the location and generalized lithological column (a) of the studied area (after Pavlides \& Mountrakis 1987) and (b) of Achlada lignite deposits, NW Greece.

The aim of the current study is to present preliminary results from analyses carried out on samples extracted from a 10 -meter thick profile in the Achlada opencast mine. The data for such analyses led to a multidisciplinary palaeocarpological, palynological, coal-petrographical, mineralogical and sedimentological study. Additionally, animal remains like cocoons and coprolites are present but no shells were found. This work is followed by an assessment and interpretation of the palaeoenvironmental conditions associated with Achlada lignite deposits, as well as the role of palaeoclimate (orbital signatures) in the evolution of the particular lignite deposits.

\section{Geological setting}

The studied area is located in the NNW-SSE trending intramontane Florina-Ptolemais-Servia (FPS) Basin, which ex- tends over a distance of $120 \mathrm{~km}$ from Bitola (Macedonia) to Servia in northwestern Greece through the cities of Florina, Amyteon and Ptolemais (Fig. 1). The basin developed in the Late Miocene in the Pelagonian Zone, the westernmost part of the Internal Hellenides (Brunn 1956), in response to NE-SW extension (Pavlides \& Mountrakis 1987). A subsequent Pleistocene episode of NW-SE extension resulted in the fragmentation of the basin into several sub-basins, i.e., Florina, Ptolemais and Servia (Pavlides \& Mountrakis 1987), which are flanked by mountain ranges that are primarily composed of Palaeozoic schists, Upper Carboniferous granites and Mesozoic limestones (Brunn 1956).

The Neogene-Quaternary sediments that fill the basin overlay unconformably both Palaeozoic metamorphic rocks and the Mesozoic crystalline limestones and can be divided into three lithostratigraphic units as follows: 1 , the lowest consists of basal conglomerates containing pebbles 
of metamorphic rocks, which pass transitionally upwards into marls, sandy marls, sands, clays and lignite layers. The age of this unit has been defined by fossils as late Miocene (Pontian) to early Pliocene (Velitzelos \& Petrescu 1981); 2 , the middle unit is clayey and contains some thick lignite beds, which alternate with clays, marls, sandy marls, and sands. Pollen analysis and a microfaunal study (Weerd 1979, Ioakim 1984) have given an early Ruscinian age (lower boundary: 5.3 Ma) for the lower members of the unit and a late Ruscinian one for the upper members (Koufos 1982); 3, the upper unit consists of terrestrial and fluvioterrestrial conglomerates, lateral fans and alluvial deposits and represents Quaternary sedimentation in the basin (Pavlides \& Mountrakis 1987).

As for tectonic activity in the studied area, normal faults are represented in the lignite beds with two main fault directions dominant, a NE-SW direction and a NW-SE one, which is almost vertical to the first one. A similar tectonic structure is presented in the Achlada coal mine sediments where the inclinations are about $15^{\circ} \mathrm{SSW}$. Additionally, big NW-SE faults drop the Neogene sediments to the SW (Pavlides \& Mountrakis 1987). Finally, the major Achlada-Scopos-Papadia fault, the direction of which is NE-SW, is an important result of Pre-Neogene neotectonic activity (Mountrakis 1983).

\section{Material and methods}

Although the lignite deposits have already been described in total, the macro-petrographical, palaeobotanical, palynological and mineralogical aspects presented here concern only the first ten meters $(0-10 \mathrm{~m})$ of the lignitebearing sequence. Because the Achlada lignite deposits present obvious differences in three parts of the opencast mine (see following paragraphs for details), the studied profile does not represent a generalized section for the whole succession but a particular section in one of the three. Lithostratigraphic features have been traced based on data from 59 samples belonging to the 10 -m profile obtained sequentially from bottom to top of the lignitebearing sequence (Fig. 2). The samples were also taken towards the direction shown in Fig. 3 in order to obtain the most representative approach. Samples and residues, numbered xx1-59 are housed in the laboratory of Mineralogy, Petrology and Economic Geology at the School of Mining

Figure 2. Macro and micro-petrographic analysis of the examined 10-m profile. The lignite-bearing sequence begins at inorganic horizon A0. Lithological column with organic and inorganic alternations plotted to the left; legend shows lithotype composition of profile; to the right are numbers of organic and inorganic samples extracted; in the fourth column are symbols of palaeobotanical finds.

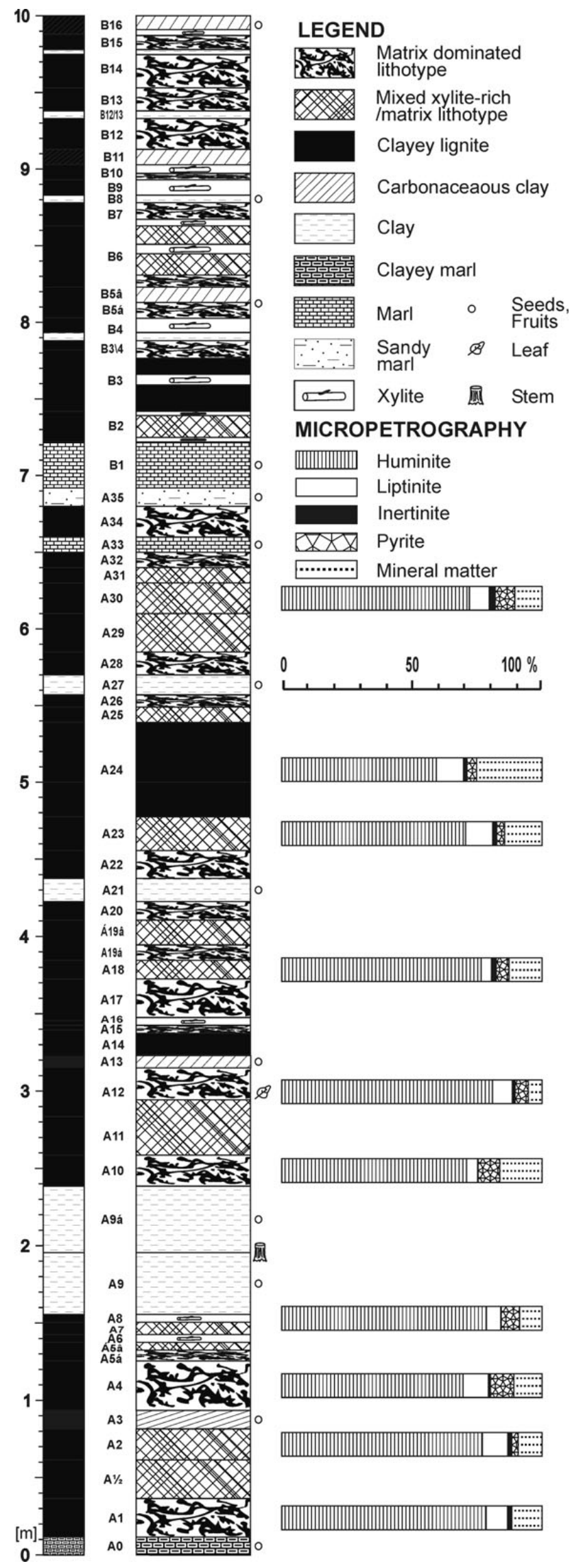


and Metallurgical Engineering of the National Technical University of Athens (NTUA).

Lithological features of each of the studied samples were macroscopically described and the lignite lithotype determined according to guidelines established by the International Committee for Coal and Organic Petrology (ICCP 1993), as well as by Taylor et al. 1998. Samples with more than $10 \%$ by volume woody tissues were logged as mixed xylite-rich/matrix, whereas that of immiscibly woody tissues was classed as xylite.

Palaeobotanical investigation comprised examination of seven samples for palynology purposes and eight for palaeocarpology (Table 4). Apart from one coal sample, the rest of the samples for both examinations originated from an inorganic intercalated seam in the lignite-bearing sequence and were prepared according to Kaiser \& Ashraf (1974). Three of the samples were from a common bed for carpology and palynology, whereas the rest (nine) were from different horizons. The investigation was carried out using an Orthoplan Leitz 307 metallographic microscope as well as a Wild M8 stereoscope.

For coal-petrographic analysis, polished blocks (Ø $3 \mathrm{~cm})$ of 10 coal samples (Fig. 2) were prepared according to international standards (American Society 1990) and also examined using the Orthoplan Leitz 307 coal-petrographic microscope (objective magnification $\times 50$, oil immersion, monochromatic light at $\lambda=546 \mathrm{~nm}$ ). Point counting for maceral analysis was conducted under reflected white and fluorescent light following the Stopes-Heerlen terminology (ICCP 1963, 1971, 2001; Taylor et al. 1998; Sýkorová et al. 2005).

The mineralogical composition of 23 samples was determined by means of X-ray diffraction (XRD), thermogravimetric (TG/DTG), differential thermal analysis (DTA), and Fourier Transform Infra Red (FT-IR) spectroscopy; all samples were taken from clastic rocks intercalated in the coal seams (Fig. 2). In order to identify the types of clay mineral occurring in the studied samples, samples were examined both in bulk and after heating up to $550{ }^{\circ} \mathrm{C}$ for 2 hours in a static oven. Samples were then cooled at room temperature and examined by X-ray power diffraction. The presence or absence of swelling clay minerals was identified by the shift or not of typical diffraction patterns (for each clay mineral) after saturation with ethylene glycol. Apart from X-ray diffraction analysis, the bulk samples were examined by means of FT-IR, DTA and TG/DTG analysis and the results from the different types of analyses were then correlated. X-ray power diffraction patterns were obtained using a Siemens D-5000 diffractometer, with Ni-filtered $\mathrm{CuKa}_{1}$ radiation $(\lambda=1.5405 \AA)$, operating at $40 \mathrm{kV}, 30 \mathrm{~mA}$. The IR measurements were carried out using a Fourier Transform Infra Red (FT-IR) spectrophotometer (Perkin Elmer 880). The FT-IR spectra, in the wavenumber range from $400 \mathrm{~cm}^{-1}$ to
$4000 \mathrm{~cm}^{-1}$, were obtained using the $\mathrm{KBr}$ pellet technique. The pellets were prepared by pressing a mixture of the sample and of dried $\mathrm{KBr}$ (sample: KBr approximately $1: 200$ ), at 8 tons $/ \mathrm{cm}^{2}$. Differential thermal analysis (DTA) and thermo-gravimetric (TG/DTG) analyses were obtained simultaneously using a Mettler Toledo 851 instrument. The samples were heated from $20{ }^{\circ} \mathrm{C}$ to $1200{ }^{\circ} \mathrm{C}$ at a constant rate of $10^{\circ} \mathrm{C} / \mathrm{min}$.

\section{Results and discussion}

\section{Petrographic analysis}

Macropetrography. - A general view of the Achlada opencast mine, which is in operation, is presented in Fig. 3. The thickness of the lignite deposits is about $35 \mathrm{~m}$ while the thickness of the overlying formations, consisting of clays, marls, sands and other sediments, is about $20 \mathrm{~m}$.

Two main characteristics of the lignite deposits, comprise typical alternations of organic and inorganic beds, as well as channels that indicate strong fluvial influence. The same model, with very frequent alternations of thin layers (of a few cm) of lignite, clay and marl was called "the big lignite deposits of Ptolemais" by Kaouras (1989). In contrast, the Achlada lignite deposits show thick lignite seams with alternations of thin clay layers.

The combination of macropetrographic analysis of the first $10-\mathrm{m}$ profile and the observations at the Achlada opencast mine resulted in the profile presented in Fig. 2. The sampling started from an inorganic horizon, named A0, which is at the base of the lignite-bearing sequence. The main characteristic of the studied profile is the alternation of matrix-dominated and mixed xylite-rich/matrix lithotypes, with in addition the presence of 12 distinct xylite horizons. Despite efforts made, no further palaeobotanical fossils were found.

From the first, the 10 -meter profile could be divided into two different units. The first one is from $0 \mathrm{~m}$ up to $3.2 \mathrm{~m}$, where the main characteristic is the presence of the mixed xylite-rich/matrix lithotype; the second is from $3.2 \mathrm{~m}$ up to $10 \mathrm{~m}$, where the occurrence of matrix-dominated lithotype is typical.

The first lignite horizon starts with a matrix-dominated lithotype without plant roots. In the first $3.2 \mathrm{~m}$ the dominance of mixed xylite-rich/matrix lithotype is evident. In addition, the lignite-bearing sequence is disrupted by a thick $(\sim 80 \mathrm{~cm})$ inorganic horizon in which vertical positioned stems are present (see description of Fig. 5B below). Two thin xylite horizons are also present in this part of the succession.

In the second unit $(3.2-10 \mathrm{~m})$, the matrix-dominated lithotype is prevalent and can be divided into three sub-sections (3.2-4.8 $\mathrm{m}, 4.8-7.5 \mathrm{~m}, 7.5-10 \mathrm{~m})$ based on the pres- 


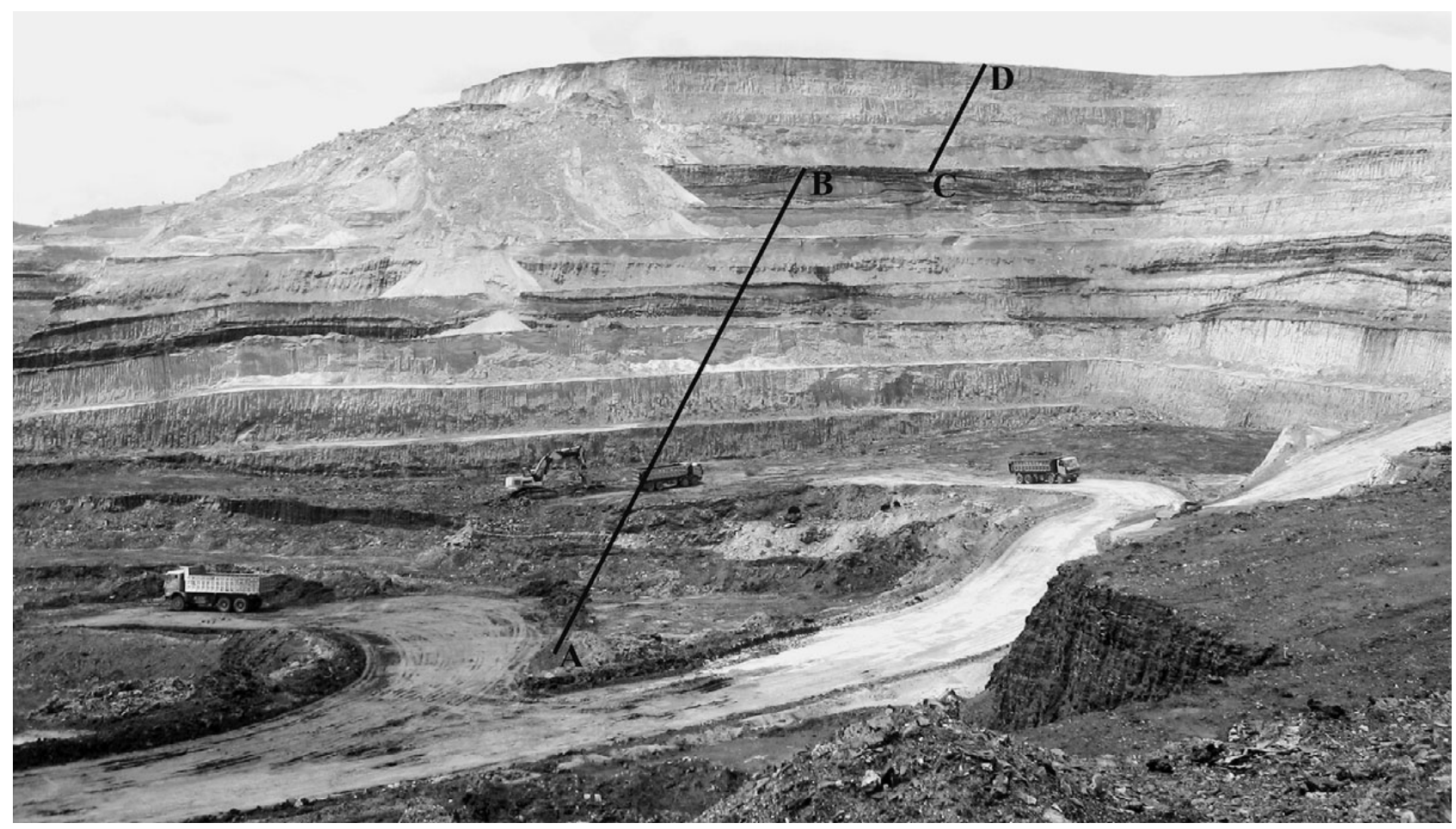

Figure 3. Photograph showing general view of Achlada lignite deposits. Black lines A-B and C-D denote the organic beds and the overlying inorganic sediments, respectively.

ence of four clayey lignite horizons. In the first sub-section, the occurrence of matrix-dominated lithotype is striking and there is also a simultaneous equivalent alternation with horizons of mixed xylite-rich/matrix lithotype. Additionally, a thin xylite horizon is present. The lignite-bearing sequence is interrupted (at about $1.6 \mathrm{~m}$, fig 2) by an about $65-\mathrm{cm}$ thick clayey lignite horizon. The second subsection is also predominantly matrix-dominated lithotype, with here the succession interrupted by both mixed xylite-rich/matrix lithotype horizons and clay ones. A xylite horizon finalizes this sub-section. Upwards, the lignite-bearing sequence discontinues and starts again with a xylite layer; xylite horizons are then typical and striking in this third sub-section. An additional observation is that the xylite horizons are inclined to dominate towards the top $(\sim 35 \mathrm{~m})$ of the total Achlada lignite-bearing sequence. This trend is already clear in the first 10 meters of the succession with the increase in xylite layers at about $7.5 \mathrm{~m}$ (Fig. 2).

Particular emphasis is given to the presence of xylite, which is found in large amounts in the Achlada lignite deposits. During the macroscopic analysis of the layers of the lignite-bearing sequence it was observed that the Achlada deposits differ from others in their many and well-preserved horizontal xylite layers (Fig. 4), the thickness of which varies from $2 \mathrm{~cm}$ up to $12 \mathrm{~cm}$ and which extend for about $15 \mathrm{~m}$.

Not only are isolated xylite parts present in the lignite mass but the thickness of these beds can also whose vary (see Fig. 4). The xylite texture of the deposits is amplified by the occurrence of large and small xylite parts as branches and stems (Fig. 5). Roots are also observed (see left Fig. 5A), and deposition continued inside the lignite horizons (right of Fig. 5A). Moreover, two smaller stems are depicted and another stem with well-preserved tissue is seen in vertical position in a huge inorganic clayey bed and presents (Fig. 5B); this particular stem continues into the overlying lignite horizon, suggesting an autochthonous character.

Micropetrographic composition and facies indices. - The maceral composition of the studied samples is summarized in Fig. 2 as well as in Table 1. From this it was determined that huminite is the dominant maceral group with a maximum percentage of $81 \%$ and a minimum of $60 \%$. Liptinite is present in all the samples with high content at the top and bottom of the studied profile with a lower content in the middle part of that and a contents ranging from $4 \%$ to $10 \%$. Distribution of inertinite presents the same behaviour as liptinite but in much lower percentages $(0.2-2 \%)$.

Humotelinite is the most prevalent maceral subgroup in the majority of the samples. Interesting is that ulminite, which contributes mainly in the form of ulminite $A$, is the most abundant maceral of humotelinites. Ulminite B only contributes in low percentages. Regarding humodetrinite, attrinite is the dominant maceral of the mixed xylite-rich/matrix lythotype and the xylite type, 
Table 1. Composition of maceral and mineral matter (vol.\%) of the Achlada lignite deposits

\begin{tabular}{|c|c|c|c|c|c|c|c|c|c|c|}
\hline Macerals & A1 & $\mathrm{A} 2$ & A4 & A8 & A10 & A12 & A18 & A23 & A24 & A30 \\
\hline Textinite A & 0.77 & 0.3 & 0 & 0 & 0 & 0 & 0 & 0 & 0 & 0.26 \\
\hline Textinite B & 0 & 0 & 0 & 0 & 0 & 0 & 0 & 0 & 0 & 0 \\
\hline Ulminite A & 18.14 & 35.7 & 38.47 & 42.63 & 40.37 & 39.15 & 39.32 & 29.44 & 23.88 & 39.64 \\
\hline Ulminite B & 11.11 & 6.4 & 1.62 & 26.43 & 2.66 & 4.23 & 1.56 & 1.02 & 0.52 & 4.92 \\
\hline ULMINITE & 29.25 & 42.1 & 40.09 & 69.06 & 43.03 & 43.38 & 40.88 & 30.46 & 24.4 & 44.56 \\
\hline Humotelinite & 30.01 & 42.4 & 40.09 & 69.06 & 43.03 & 43.38 & 40.88 & 30.46 & 24.4 & 44.82 \\
\hline Attrinite & 21.76 & 15.8 & 21.13 & 5.73 & 8.28 & 4.76 & 16.67 & 25.89 & 24.67 & 15.03 \\
\hline Densinite & 25.12 & 15.3 & 6.23 & 2.24 & 17.91 & 21.42 & 13.54 & 11.17 & 8.14 & 0.52 \\
\hline Humodetrinite & 46.88 & 31.1 & 27.36 & 7.97 & 26.19 & 26.18 & 30.21 & 37.06 & 32.81 & 15.55 \\
\hline Porigelinite & 0 & 0.3 & 0 & 0 & 0 & 1.32 & 0 & 0.25 & 0 & 0 \\
\hline Levigelinite & 0 & 0 & 0 & 0 & 0 & 0 & 0 & 0 & 0 & 0 \\
\hline Corpohuminite & 1.554 & 3.2 & 2.16 & 1.49 & 2.67 & 10.05 & 5.47 & 2.8 & 2.62 & 11.65 \\
\hline Humocollinite & 1.554 & 3.5 & 2.16 & 1.49 & 2.67 & 11.37 & 5.47 & 3.05 & 2.62 & 11.65 \\
\hline HUMINITE & 78.48 & 77 & 69.61 & 78.52 & 70.89 & 80.93 & 76.36 & 70.57 & 59.83 & 72.02 \\
\hline Fusinite & 0 & 0 & 0.27 & 0 & 0 & 0 & 0 & 0 & 0 & 0 \\
\hline Funginite & 1.29 & 1.6 & 0.54 & 0.25 & 0.26 & 1.06 & 1.3 & 1.02 & 0.26 & 1.3 \\
\hline Inertodetrinite & 0 & 0 & 0 & 0 & 0 & 0 & 0.52 & 0.51 & 1.05 & 1.04 \\
\hline Macrinite & 0 & 0 & 0 & 0 & 0 & 0 & 0 & 0 & 0 & 0 \\
\hline INERTINITE & 1.29 & 1.6 & 0.81 & 0.25 & 0.26 & 1.06 & 1.82 & 1.53 & 1.31 & 2.34 \\
\hline Sporinite & 2.849 & 2.1 & 0.81 & 0.75 & 1.34 & 1.59 & 0.26 & 2.28 & 2.36 & 1.04 \\
\hline Cutinite & 2.07 & 2.6 & 1.08 & 4.73 & 0.8 & 0 & 0 & 0.76 & 0.52 & 1.81 \\
\hline Resinite & 0 & 0.3 & 0 & 0 & 0 & 0 & 0 & 0 & 0.79 & 1.81 \\
\hline Suberinite & 1.29 & 1.07 & 0.81 & 0 & 0.8 & 4.23 & 0.52 & 0 & 0.52 & 2.6 \\
\hline Alginite & 0 & 1.3 & 2.98 & 0 & 0.26 & 1.05 & 0.78 & 4.06 & 3.94 & 0 \\
\hline Liptodetrinite & 2.07 & 2.4 & 1.89 & 0 & 1.06 & 0.8 & 2.34 & 3.3 & 2.36 & 0.26 \\
\hline Fluorinite & 0 & 0 & 0 & 0 & 0 & 0 & 0 & 0 & 0 & 0 \\
\hline LIPTINITE & 8.279 & 9.8 & 9.73 & 5.48 & 4.26 & 7.67 & 3.9 & 10.4 & 10.49 & 7.52 \\
\hline Clay minerals & 10.1 & 7.2 & 11.92 & 6.98 & 15.24 & 5.03 & 12.76 & 13.7 & 23.88 & 8.81 \\
\hline Pyrite & 0.259 & 2.4 & 8.94 & 6.12 & 8.28 & 4.82 & 4.95 & 3.04 & 3.67 & 7.51 \\
\hline Carbonate & 0 & 1.07 & 1.89 & 1.74 & 0 & 0.26 & 0 & 0.76 & 1.31 & 1.81 \\
\hline Mineral matter & 10.36 & 10.7 & 23.29 & 15.7 & 23.32 & 10.32 & 17.71 & 17.5 & 28.86 & 18.13 \\
\hline \multicolumn{11}{|l|}{ Indices } \\
\hline TPI & 0.673 & 1.452 & 1.554 & 8.852 & 1.745 & 1.943 & 1.508 & 0.879 & 0.798 & 3.404 \\
\hline GI & 2.348 & 3.441 & 2.21 & 12.17 & 7.448 & 13.09 & 3.239 & 1.629 & 1.353 & 3.218 \\
\hline
\end{tabular}

whereas densinite is present in higher values in the matrix lithotypes. Humocollinite displays low to moderate values (1.5-12\%), with corpohuminite being the predominant maceral. The latter is also frequently accompanied by suberinite. Porigelinite occurs up to $1.2 \%$. No levigelinite was found.

The values of liptinite vary according to the lithotype and more specifically, the mixed xylite-rich/matrix lithotype display liptinite contents with an average of $8 \%$, compared to $7 \%$ in the matrix ones. Sporinite and liptodetrinite are the most frequent macerals, followed by cutinite and alginite. Inertinite does not exceed values greater than $2 \%$. The most common are funginites and inertodetrinites.
Clay minerals dominate in all the samples with amounts up to $24 \%$, while pyrite contributes with values up to $9 \%$. Carbonates contribute only low amounts in all samples. However, it should be noted that the identification of minerals using the reflected-light microscope is problematic and, thus, only approximate.

Representative microphotographs of the various maceral associations are shown on Fig. 6. Both ulminite-A and ulminite-B are present (Fig. 6A), and they are connected by a gelinite mass. Densinite occurs and a typical form of corpohuminite is noteworthy (Fig. 6), with a cyclic form with an accumulation of resinites in the centre. When seen in fluorescence light the presence of resinites is 
clearly shown in the centre of corpohuminites. A very beautiful accumulation of alginite is present (Fig. 6E). Finally (Fig. 6G), there is a typical occurrence of framboidal pyrite. Inorganic matter varies from 10 to $29 \%$ comprising clay minerals, pyrite, and other accessory minerals. The maximum content of clay minerals was found in sample A24 of clayey coal whereas lower amounts of clays were in matrix coal in the lower part of the profile (Fig. 2). The pyrite content is relatively high $(0.2-9 \%)$ and is found mostly in the framboidal form (Fig. 6G), suggesting enhanced activity of sulphate-reducing bacteria, probably related to carbonate and sulphate-rich waters in the basin during peat formation (Kuder et al. 1998, Teichmüller et al. 1998, Stachura \& Ratajczak 2004).

Due to the fact that a combination of sedimentological, geochemical, palaeobotanical, palynological and biological studies should be applied to define the origin of coal deposits (Collinson \& Scott 1987, Shearer et al. 1995, Scott 2002, Moore \& Shearer 2003), in this study the use of maceral ratios is only indicative and complementary to the palaebotanical features and not a panacea for the delineation of the palaeoenvironmental conditions.

The ternary diagram proposed by Mukhopadhyay (1989) provides a first view of the depositional conditions; he also used the humodetrinite/humotelinite ratio to differentiate between swamp-dominated, swamp-marsh, and marsh-dominated coal environments. When this ratio is used, all the samples showed values $<1.5$ and reflect distribution in the swamp-dominated area (not shown).

Furthermore, by plotting the results of the maceral analysis on Mukhopadhyay's (1989) ternary diagram (Fig. 7), it seems that the peat accumulated under highly saturated and

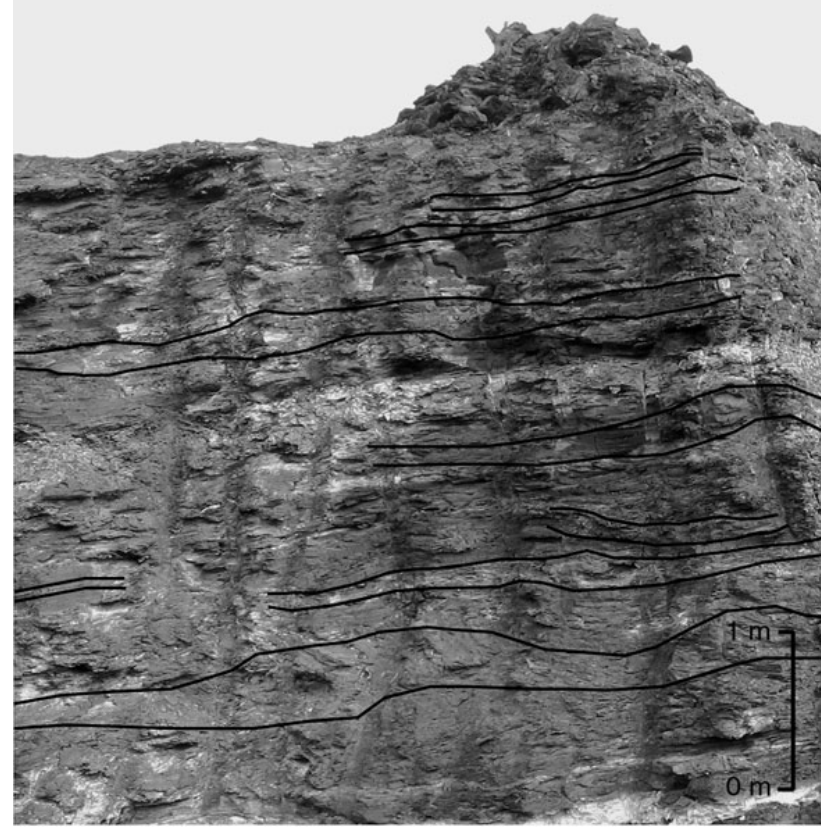

Figure 4. Xylite beds in the lignite deposits. Bold lines indicate the xylite horizons.

intensely anoxic conditions. Most of the samples plot close to apex A, suggesting forested vegetation and good tissue preservation and, in addition, the indicated depositional environmental conditions were similar irrespective of which model (or modified version) was used. Sample A8 plotted very close to apex $\mathrm{A}$, indicating better tissue preservation in comparison to the other samples. This good material originates from lignin-rich plants especially immiscible woody species from a horizon that is part of a xylite body occurring
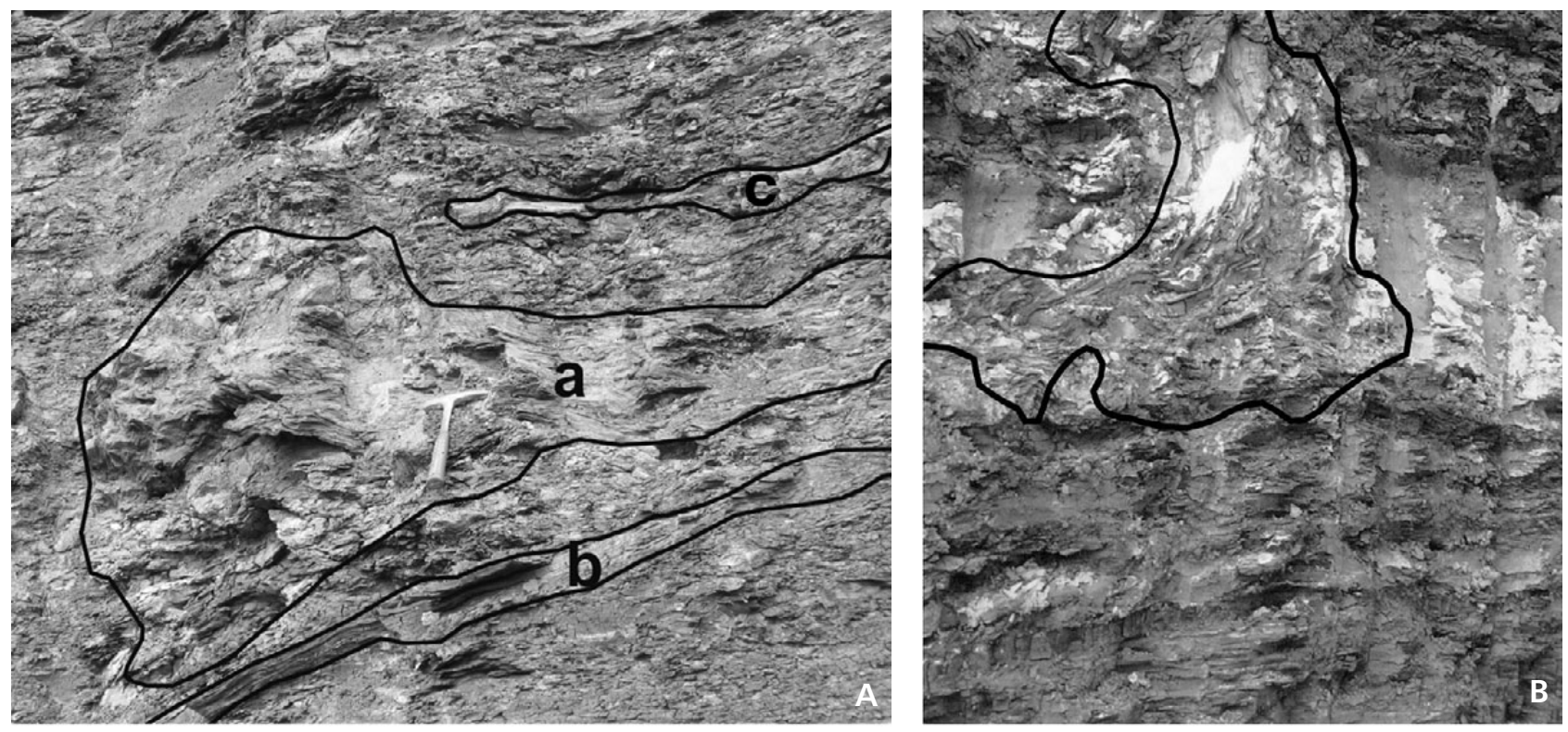

Figure 5. A - horizontal position of a huge stem inside a lignite bed (a). Two almost horizontal xylite parts (b and c). $\bullet$ B - vertical positioned stem inside an inorganic horizon. 
within the lignite mass. The same xylite body comprises also two other horizons (A6 and A7) lying under A8, while in the overlying A9 clayey horizon there is the possibly autochthonous vertical situated stem (see above and Fig. 5B), the upper part of which is incorporated into the overlying matrix horizon A10. From a palaeoenvironmental point of view, the combination of a xylite body occurrence and a constant succession of either mixed xylite-rich/matrix horizons or xylite ones (1.25-2.65 m, Fig. 2) suggests that the area, where an independent cluster of trees occurred, was little by little converted into wet forest swamp where the forested vegetation contributed to peat formation, after which a flood episode stopped the peat accumulation and deposited a thick clayey horizon.

The tissue preservation (TPI) and gelification indices (GI) proposed by Diessel $(1986,1992)$ have been used for evaluating the depositional palaeoenvironment. The TPI is an indicator of the degree of organic tissue preservation in a palaeomire, as well as a function of the contribution of arboreal vegetation to peat formation. The GI reflects the homogenization (sensu gelification) of organic matter. TPI and GI indices had previously been modified (Kalkreuth et al. 1991, Sakofara \& Michailidis 1997, Markic \& Sachsenhofer 1997, Kalaitzidis et al. 2001, Flores 2002, Mavridou et al. 2003, Iordanidis \& Georgakopoulos 2003 and Zdravkov et al. 2006) and here, we have used the ratios modified by Kalaitzidis et al. (2001). These modifications were applied to the indices proposed by Markic \& Sachsenhofer (1997), and include the introduction of gelinite and inertodetrinite as nonstructured macerals in the denominator of TPI and gelinite in the numerator of GI. Previous coal-petrographic studies on Greek lignites (Kalaitzidis et al. 1998, 2000, 2001; Antoniadis et al. 2001; Papazisimou 2002) showed that, by using these indices, the assessment of peat-forming palaeoenvironments corresponds better to the conditions of lignite formation in Greece. Moreover, a recent study concerning the Amynteon lignite in the Ptolemais Basin (Mavridou et al. 2003) was based on the same indices. The formulas used for TPI and GI are:

$\mathrm{TPI}=\frac{\text { humotelinite }+ \text { corpohuminite }+ \text { fusinite }}{\text { attrinite }+ \text { densinite }+ \text { gelinite }+ \text { inertodetrinite }}$

$\mathrm{GI}=\frac{\text { ulminite }+ \text { humocollinite }+ \text { densinite }}{\text { textinite }+ \text { attrinite }+ \text { inertinite }}$

The TPI values range between 0.7 and 3.4 for nine samples (Table 1; Fig. 8), with the higher values corresponding to mixed xylite-rich/matrix ones, while for sample A8 the value is exceptionally high (8.8). Probably, organic matter preservation was moderately to intensely favoured, since all samples display TPI $>0.1$. Additionally, the preservation of structured tissues, as an index of humification intensity, was low to moderate for soft cellulose-rich plant materials (herbaceous species) and high for lignin-rich plant materials (woody species) such as sample A8. The GI values fluctuate from 1.4 to 3.4 for the majority of samples revealing low to moderate gelification of the organic matter.

Reading the TPI vs. GI plot (Fig. 8), it seems that the majority of samples were accumulated in the field representing 'wet forest swamp'. The sample distribution is in accordance with the other palaebotanical results and shows that the forest swamp environment was periodically converted to a limnic one when both the TPI and GI were lowered. Additionally, a previous study (Antoniadis et al. 2001) supported the presence of a telmatic environment under mainly mesotrophic to rheotrophic hydrological conditions.

Samples A8 (xylite) and A30 (mixed xylite-rich/matrix coal), which as noted above present a higher TPI (>3.5) than the other eight, are exceptional and indicate the possible occurrence of a piedmont plain environment. Although the number of analyzed samples is only indicative, the hypothesis that many independent clusters of trees were present in the Neogene of the studied area is supported both by the occurrence of the piedmont plain plot in Fig. 8 and the presence of xylite bodies within the lignite mass in many independent positions. Furthermore, floodplain fens occur upon badly-drained floodplains of some rivers and streams frequently experiencing episodic inundation, either directly from adjoining watercourses or because high river water levels help to 'pond back' land-drainage and rainwater inputs (Giller \& Wheeler 1986). The presented piedmont plain environment in comparison to the wet forest swamp, probably means that small parts of the former in which clusters of trees grew were periodically flooded (because of either small stream contribution originating from the surrounded mountains or the inundation of the main river system of the general area) converting it into a wet forest swamp. Afterwards, this swamp was established, as revealed by the palaebotanical data, a reedmoor type of vegetation grew together with various types of forest.

\section{Palaeobotanical characteristics}

As a whole the flora is poor in species and specimens. Mentioned among the finds is yielded material, mostly seeds; charcoal as fusinite, fungal perithecia and other plant debris.

Palynology. - Seven samples (Table 3) were completely analyzed for palynological inclusions. All samples allowed a preliminary qualitative estimation. Families, genera and species found during the process of analysis are plotted in Table 3. From this, by using typical pollen grains for each individual facie, we reconstructed the palaeoenvironment in which the Achlada lignite deposits were formed. 

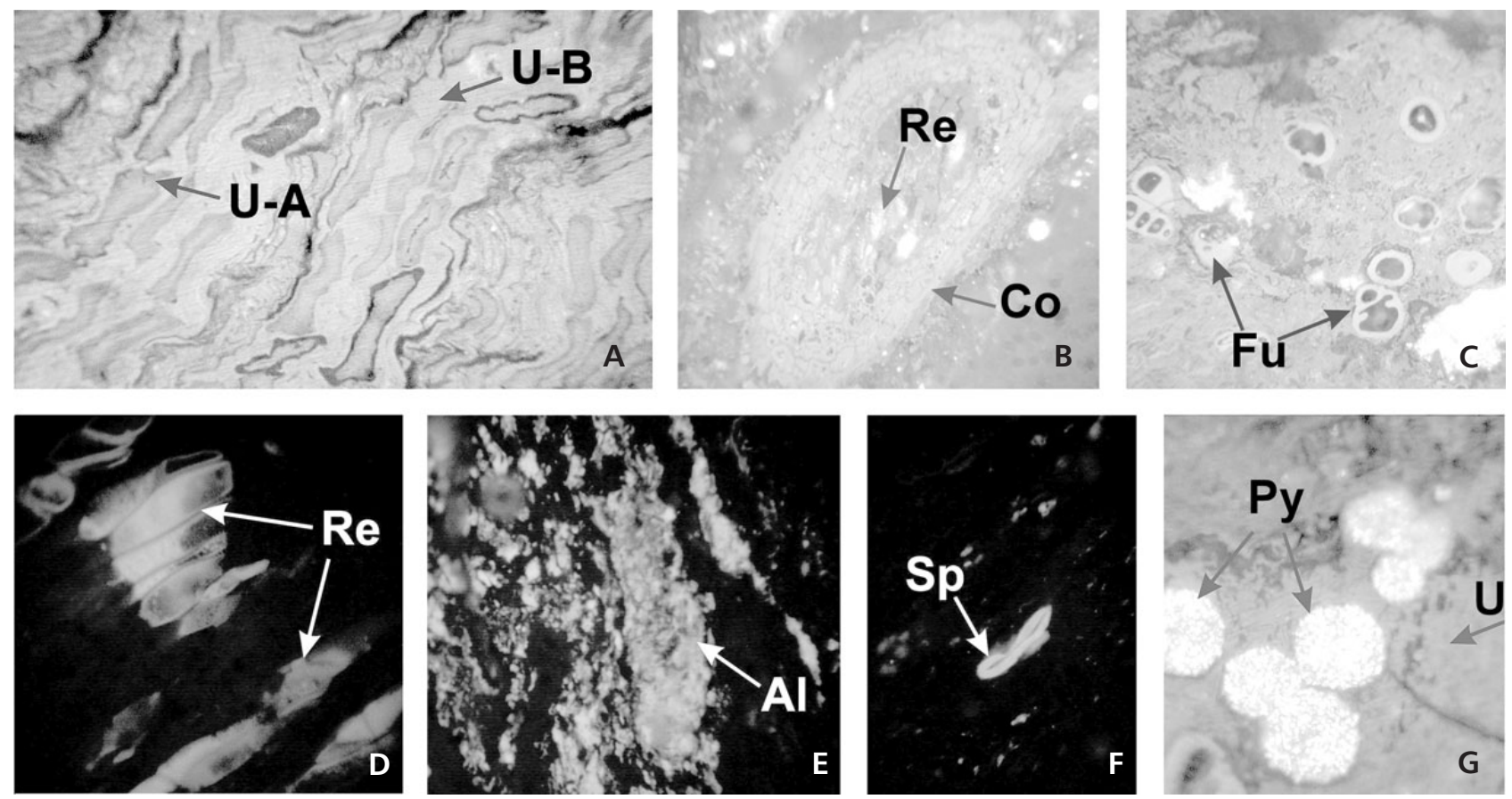

Figure 6. Photomicrographs of various macerals and pyrite within the coal matter from the Achlada lignite deposits. All photos were made both with reflected white and fluorescent light under oil immersion. • A - ulminite A (dark) (U-A) and ulminite B (U-B), magnification 50x. B - typical cyclic form of corpohuminite $(\mathrm{Co})$ and resinite $(\mathrm{Re})$ in rootlet section with dispersed framboidal pyrite (white), 50x. $\bullet \mathrm{C}$ - typical funginite (Fu) habitation, 50x. $\bullet \mathrm{D}$ - resinite $(\mathrm{Re}), 50 \mathrm{x} \cdot \bullet \mathrm{E}$ - alginite $(\mathrm{Al})$ accumulation, 50x. $\bullet \mathrm{F}-$ sporinite $(\mathrm{Sp}), 50 \mathrm{x} \cdot \bullet \mathrm{G}-$ framboidal pyrite $(\mathrm{Py})$ within ulminite $(\mathrm{U}), 50 \mathrm{x}$.

Ovoidites, green algae, cysts of the family Zygnemataceae (Rich et al. 1982), which is a representative of a reedmoor environment and is present in almost all Greek lignite deposits (Riegel 1965, Nickel 1987, Kaouras 1989), has been found in Achlada only in sample A13 with a percentage of about $1 \%$. The total algal mass from all samples with percentages of about $15 \%$, is considered to represent plankton that coexisted with the plant association which characterizes the reedmoor environment.

Fern spores are represented by Laevigatosporites haardi from the family Polypodiaceae; they appear in low percentages in the lower seams of the profile (Table 3 ). The occurrence of polypodiacean spores is typical for transitional environments characterised for instance, by the transition from fresh water to mixed forest or semi-fresh reedmoor environment, as it occurs in recent peat deposits on eastern American shoreside areas (Riegel 1965).

A reedmoor environment is also represented by the appearance of Gramineae, the occurrence of which assures the presence of a reedmoor area or one adjacent. A large percentage part may belong to Phragmites communis, which occurs in any reedmoor area. In addition, the Sparganiaceae, which are present in the same area, are also typical of a reedmoor environment.

The Pinaceae contribute only in minor amounts and also are not present in all samples. Low percentages of Pinus have also been noticed in other Greek lignite deposits, regarding sub-aquatic facies in Ptolemais (Kaouras
1989) and the Taxodiaceae forest facies at Aliveri (Riegel et al. 1989), which is connected with an increase of Mediterranean vegetation types at Megalopolis owing to warmer interglacial climatic conditions during the Quaternary period (Nickel 1987).

Typical pollen grains of Aceraceae, Tilia, Myrica and Betula, indicating a mixed forest environment, are also present in the studied profile. An additional datum with a strong indication of a reedmoor environment influence is the occurrence of pollen from the families Cyperaceae and Compositae.

The presence of Sequoia in sample B16 at the top of the succession is also remarkable, and further detailed analyses of all samples might reveal whether this taxon is of autochthonous or allochthonous origin.

Palaeocarpology. - The results of a preliminary carpological analysis on eight samples taken from clastic rocks intercalated in the coal seams are shown in Table 4. The fossil remains including the seeds are mostly poorly preserved, strongly gelified, squashed and difficult to determine. Looking at the plant association types revealed from the analysis, water, reed, swamp and mesophitic palaeoenvironments are distinct. Furthermore, lianas, epiphytes (Ampelopsis sp., Lorantaceae) and fungi (Cenococcum geophilum, Perithecia indet., Rosellinites areolatus) are present. Surprisingly, signs (mesophytic elements) of drier conditions are dominant, which is also confirmed by the presence of the fungi and lianas, which grow in drier habitats. 


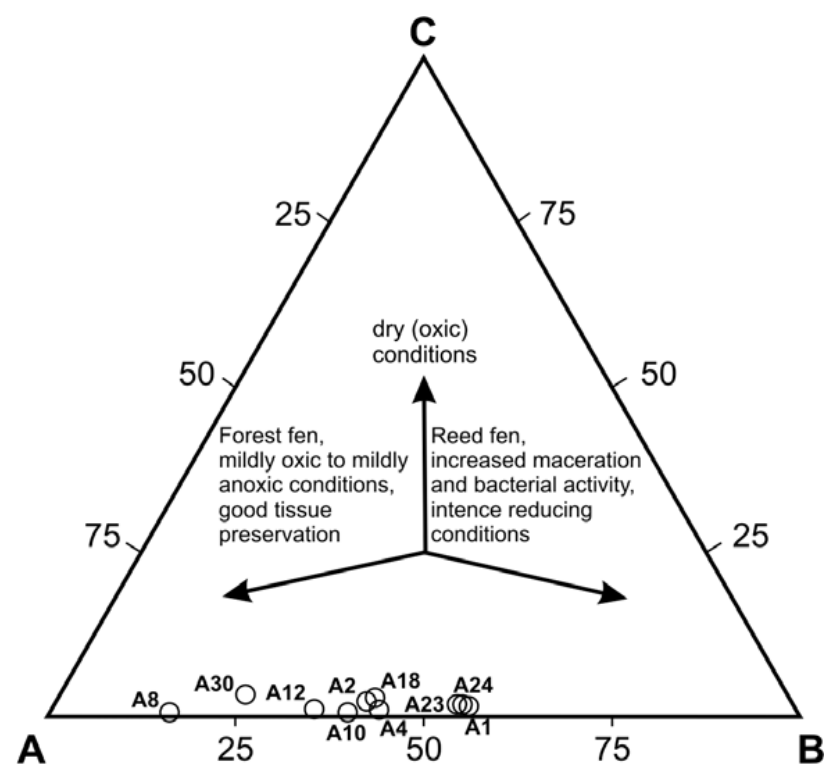

Figure 7. Ternary diagram showing the palaeoenvironmental conditions for 10 samples from the Achlada lignite deposits, according to Mukhopadhyay (1989). A = telohuminite + corpohuminite + sporinite + cutinite + resinite + suberinite + fluorinite, $\mathrm{B}=$ detrohuminite + gelinite + liptodetrinite + alginite, $\mathrm{C}=$ inertinite.

Table 2. Characteristic FT-IR bands of a representative sample from a thick inorganic layer $2 \mathrm{~m}$ above the base of the Achlada lignite sequence.

\begin{tabular}{lc}
\hline Assignment & Wave number $\left(\mathrm{cm}^{-1}\right)$ \\
\hline stretching vibration of $\mathrm{OH}$ groups & 3699,3618 \\
$\mathrm{H}-\mathrm{O}-\mathrm{H}$ stretching vibration of absorbed water & 3428 \\
$\mathrm{H}-\mathrm{O}-\mathrm{H}$ bending vibration of absorbed water & 1629 \\
Si-O-Si stretching vibration & 1032 \\
Si-O-Al $^{\mathrm{VI}}$ stretching vibration & 1013 \\
Si-O $_{\text {apical }}$ stretching vibration of Si-O & apical \\
Si-O-Al & 1104 \\
Si-O-Si bending vibrations & 534 \\
stretching vibration of O-C-O groups & 468 \\
\hline
\end{tabular}

The combined palaeobotanical study revealed that arboreal plants as well as herbaceous ones contributed to the peat formation of the Achlada lignite deposits. Furthermore, these data support the macropetrographic division of the lignite-bearing sequence into two different sections, which suggested that the peat-forming vegetation consisted mainly of mixed forest vegetation for the lower section and reedmoor and open water for the upper section.

Finally, from the stratigraphical point of view, Meliosma is a Neogene type also Symplocos and Sambucus, Potamogeton piestanensis is more typical of Pliocene. The presence of Glyptostrobus europaeus and Glyptostrobus sp. are ubiquitous. Recent studies (Ticleanu \& Diaconiță 1997, Kovar-Eder et al. 2001) suggest that Glyptostrobus europaeus is frequently accompanied by in-
Table 3. Palynological analysis at Achlada seams.

\begin{tabular}{|c|c|c|c|c|c|c|c|}
\hline & B16 & B6 & A35 & A 27 & A13 & A9 & A3 \\
\hline Ovoidites & & & & & + & & \\
\hline Plankton & + & + & + & + & + & + & + \\
\hline Sparganiaceae & & & & & & + & \\
\hline Gramineae & & + & + & & + & + & \\
\hline Cyperaceae & & & + & + & & + & + \\
\hline \multicolumn{8}{|l|}{ Palmae } \\
\hline Magnoliaceae & + & & & & & & \\
\hline Fagus & & + & + & & & & \\
\hline Acer & & + & & & & & \\
\hline Compositae & & & & + & & & \\
\hline Tilia & & + & & + & & & \\
\hline Cyrillaceae & & & & + & & & \\
\hline Myrica & & & + & & + & & + \\
\hline Carpinus & & & + & & + & & \\
\hline Alnus & & + & & + & + & & \\
\hline Betula & & & + & & + & + & \\
\hline Ulmus & & & & & & + & \\
\hline Sequoia & + & & & & & & \\
\hline Taxodiaceae & + & + & & + & & + & \\
\hline Polypodiaceae & & & & & + & + & + \\
\hline Pinaceae & + & & & + & & + & + \\
\hline
\end{tabular}

Table 4. Palaeocarpological analysis at Achlada seams.

\begin{tabular}{|c|c|c|c|c|c|c|c|c|}
\hline & B11 & $\mathrm{B} 1$ & A35 & A33 & A21 & A13 & A9 & A0 \\
\hline Epiphytes & & & & + & + & & & \\
\hline Algin & & & + & + & & & & + \\
\hline Nymphaeaceae & & & + & & & & & \\
\hline Potampgeton & + & & & & & & + & \\
\hline Batrachium & & & & & & & + & \\
\hline Sparganium & & & + & & + & & & + \\
\hline Decodon & & & + & & & & + & \\
\hline Epipremnites & & & & & & & + & \\
\hline Glyptostrobus & + & + & & & & & & \\
\hline Actinidia & & & & & & & & + \\
\hline Meliosma & & & & + & & + & + & \\
\hline Pterocarya & & & & & + & + & & \\
\hline Rubus & & + & + & & + & & & + \\
\hline Sambucus & & + & & & & & & \\
\hline Symplocos & & & & + & & & & \\
\hline
\end{tabular}

tense growth of herbaceous vegetation and open-water elements, while Stach et al. (1982) and Taylor et al. (1998) stated that the growth of members of the family Taxodiaceae (e.g., swamp cypress) requires humid climate conditions. This kind of vegetation implies a wet and warm climate with average temperatures of the coldest winter 


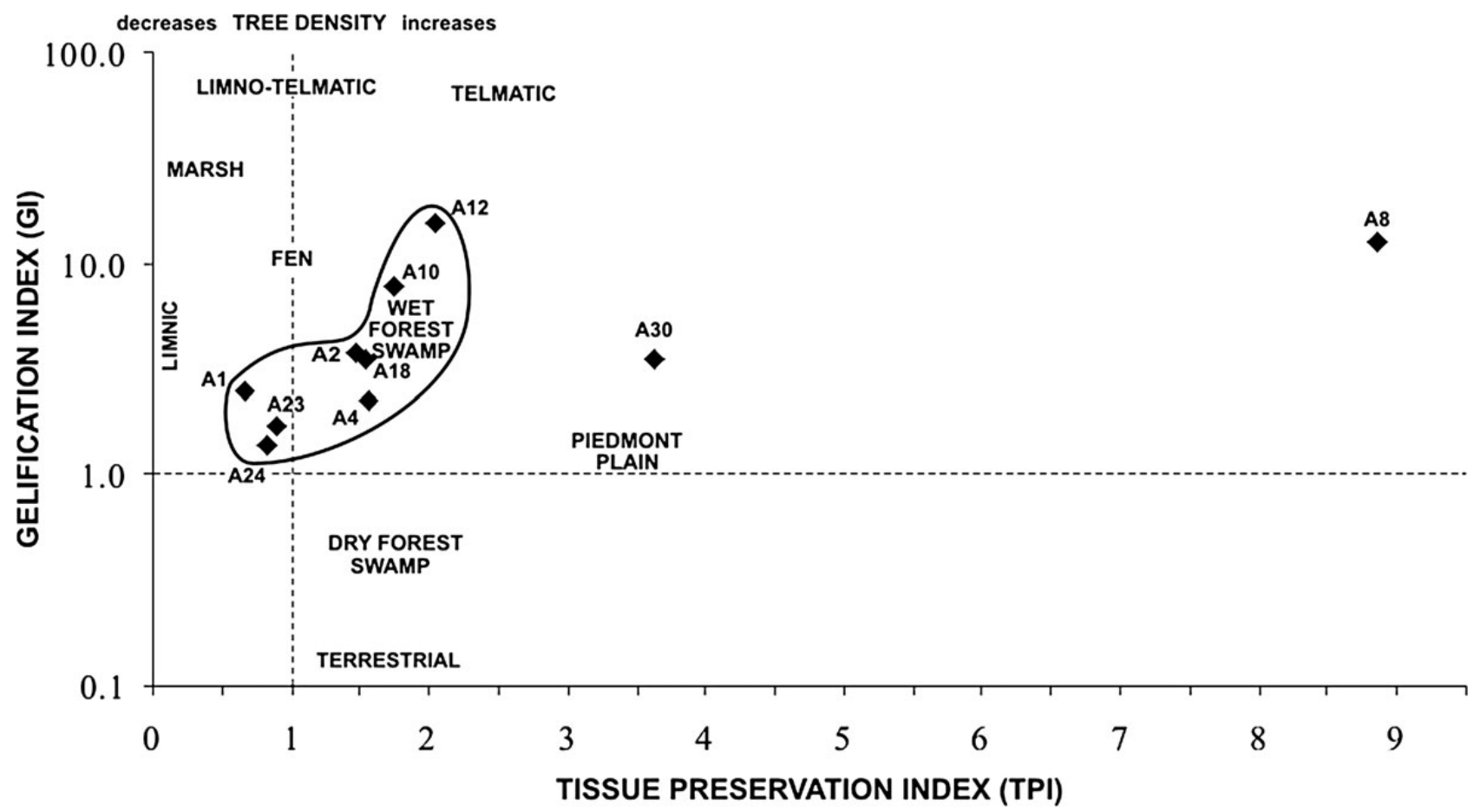

Figure 8. Diagram of TPI/GI of the Achlada lignite deposits (modified from Diessel 1986 and adjusted for Greek Tertiary lignites by Kalaitzidis et al. 2001).

month $+6{ }^{\circ} \mathrm{C}$ for Taxodium and +5 to $+10{ }^{\circ} \mathrm{C}$ for Glyptostrobus, while for the warmest months temperature could reach $+30{ }^{\circ} \mathrm{C}$ (in Kloosterboer-van Hoeve 2000). Moreover, Kalaitzidis et al. (2004) showed the significant contribution of Glyptostrobus europeus in peat formation of a specific lignite seam, named the Upper Xylite Layer, which is part of the Neogene Ptolemais Basin lignite deposits. The latter is adjacent to the Florina Basin.

\section{Mineralogical composition}

Due to the fact that mineral matter plays a major role in the evolution of a lignite sequence, thorough analysis was accomplished to determine the mineralogical composition of inorganic horizons intercalated in the coal seams of the Achlada lignite deposit. Clay minerals prevail in all samples, with illite-muscovite being the dominant phase, and kaolinite and chlorite the next. No smectite was found in the studied samples, as its typical peak (100) is not shifted from $\mathrm{d}=\sim 14 \AA$ to lower $2 \theta(\mathrm{d}=\sim 17 \AA)$ after saturation with ethylene glycol. In addition, the other mineral phases identified are mainly quartz and feldspars. The presence of siderite, in the majority of samples, is also obvious.

Quartz is identified by its typical peaks (101) at $\mathrm{d}=3.34 \AA$ and (100) at $d=4.26 \AA$; feldspars are identified by the peaks (002) at $\mathrm{d}=\sim 3.19 \AA$ and (220) at $\mathrm{d}=\sim 3.24 \AA$; illite-muscovite is identified by the sharp diffraction peak (001) at d $=\sim 10 \AA$ and (003) at d $=\sim 3.34 \AA$; kaolinite is identified by its typical peaks (001) and (002) at $\sim 7.1 \AA$ and $\mathrm{d}=\sim 3.5 \AA$; and chlorite by the peaks $(001)$ and $(002)$ at $\mathrm{d}=$ $\sim 14 \AA$ and $\mathrm{d}=\sim 7 \AA$, respectively.

An x-ray diffraction diagram of a representative orientated sample (a thick layer at $2 \mathrm{~m}$ above the base of the sequence) shows a combined kaolinite-chlorite peak, which also appears in a glycolated sample, identified by their thermal behaviour. When the samples were heated up to $500^{\circ} \mathrm{C}$, the intensity of the characteristic diffraction patterns at $\mathrm{d}=$ $\sim 7.07 \AA$ and $\mathrm{d}=\sim 3.52 \AA$ decreased due to the collapse of the mineral, clearly indicating the presence of kaolinite.

The representative sample when examined by means of FT-IR confirmed the presence of illite-muscovite, kaolinite and chlorite. The non-clay minerals are mainly siderite $\left(\sim 1405 \mathrm{~cm}^{-1}\right)$ and quartz $\left(\sim 780 \mathrm{~cm}^{-1}\right)$. The main FT-IR bands of the representative sample are summarized in Table 2 (Deng et al. 2002, Jaarsveld et al. 2002, Madejova 2002).

Thermal study curves for a sample from a layer $3.2 \mathrm{~m}$ above the base of the sequence exhibits the characteristic endothermic peak at $\sim 550{ }^{\circ} \mathrm{C}$ on the DTA curve is attributed to the dehydroxylation of the kaolinite (due to loss of $\mathrm{OH}$ groups, surrounding the $\mathrm{Al}^{\mathrm{VI}}$ atoms) and the progressive transformation from the octahedral co-ordinated $\mathrm{Al}$ in kaolinite, to a tetrahedral co-ordinated form, in metakaolinite, through the breaking of $\mathrm{OH}$ bonds (Jaarsveld et al. 2002). Considering the presence of siderite, a part of the weight loss in this temperature range comes from the decomposition of siderite according to the 


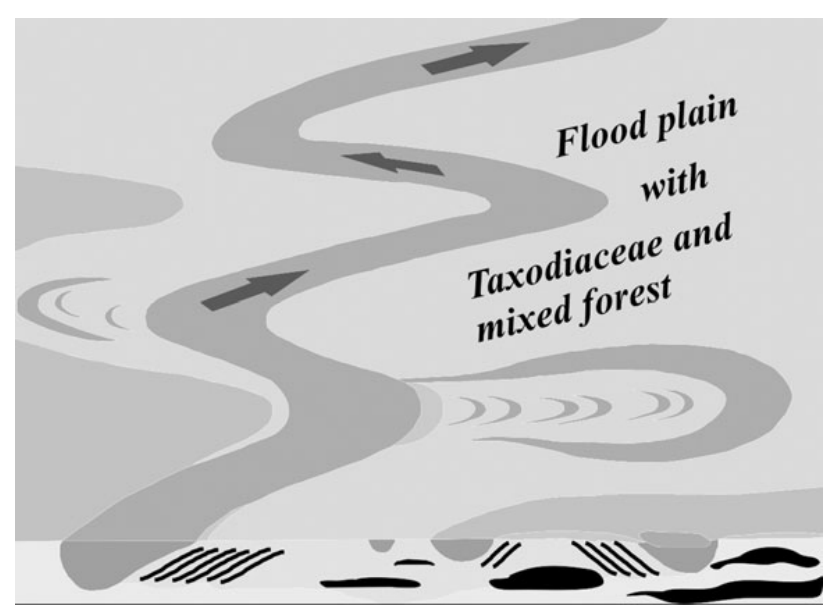

Figure 9. Depositional palaeoenvironment of the general area.

reaction $\mathrm{FeCO}_{3} \rightarrow \mathrm{FeO}+\mathrm{CO}_{2}$. Chlorite and illite-muscovite give endothermic peaks at higher temperatures.

McCabe (1984) stated that the mineralogical features of the coals depend on the dominant conditions during peat accumulation and therefore contribute to the interpretation of the coal facies. The presence of clastic quartz grains suggests intense surface water influx and supply of inorganic material inside the peat formation area. The predominance of illite-muscovite and the relative abundance of chlorite possibly originate from the fact that under warm or hydrolyzing conditions on the landscape around the swamp, chlorite weathers easily and the illite-muscovite abundance increases (Asikainen et al. 2007). Moreover, Oikonomopoulos et al. (2007) showed the prevalence of illite-muscovite in a mixed forest area in which plant communities comprising Taxodiaceae, Betulacceae, Ulnus and others were present. This type of vegetation is also an indicator of warm and humid conditions. Considering the presence of carbonate rocks in the surrounded area in the Neogene, the occurrence of siderite is not peculiar. Furthermore, the slow precipitation kinetics of siderite may in part explain the significant supersaturation with this particular mineral that is often observed in anaerobic aquatic environments (Jensen et al. 2002).

\section{Depositional palaeoenvironment}

According to the palaeobotanical results, the mineralogical analysis of the intercalated inorganic horizons of the coal seams, and the sedimentological characteristics of the Achlada lignite deposits, an attempt has been made to reconstruct the depositional palaeoenvironment of the general area. The model given in Fig. 9 depicts a major meandering river system. The macroscopic observations provided evidence about sedimentological structures in the known channels. Traces of point bars were present, while no cre- vasse splays were found. At the right side of the river system an abandoned channel is present. The thick lignite beds in this specific and small area, as well as the presence of only a few and thin inorganic layers intercalated in the coal seams, gives the impression that a peat swamp possibly formed in an oxbow-lake environment within the abandoned channel. The latter is supported by the geometry of the Achlada lignite deposits as revealed after research activity by the Public Power Corporation in 1999. Moreover, the petrographic, palaebotanical and mineralogical data indicate that the whole study area, which presents thinner coal seams in comparison to oxbow lakes as well as more frequent and thicker inorganic layers intercalated in the coal seams, constituted a wide floodplain.

As a whole, the Achlada lignite deposits can be divided into three different palaeoenvironments: the main river channel, the floodplain of the river system, and the oxbow lake. The floodplain model, in combination with the formation of the oxbow lake within the abandoned channel, represents a landscape with predominantly swampy conditions and periodical flood episodes together with the deposition of fine sediments.

Stratigraphical research on the typical alternations of organic and inorganic horizons in the Achlada lignite deposits is still in progress, and already there are interesting macroscopic observations to be made, such as the rhythmic deposition of lignite-grey clay and the distinction of six sedimentological cycles. Because of these observations, a study has been started concerning the correlation of the rhythmic deposition with orbital forcing (Milankovitch 1941) and the potentiality for the construction of a cyclostratigraphical model based on a correlation of the six sedimentological cycles and two units that have already been identified by macropetrographic examination.

\section{Conclusions}

The palaeobotanical, coal-petrographic, sedimentological, and mineralogical features of the Achlada lignite deposits suggest that the general area was a floodplain environment in the Neogene to Quaternary past, which was traversed by a principal meandering river system. The macropetrographic characteristics of the lignite-bearing sequence imply that its lower part $(10 \mathrm{~m})$ can be divided into two different units, with the lower dominated by mixed xylite-rich/matrix lithotypes and the upper one by matrix-dominated lithotype. Xylite horizons constitute the main characteristic of the Achlada deposits and occur in both sections with either autochthonous or allochthonous origin. Both length and frequency of the xylite horizons indicate the occurrence of many independent xylite bodies that significantly contributed to peat formation. The micropetrographic composition for both units are characterized 
by the prevalence of huminite ( $>60 \%$ ) with the average content of liptrinite higher in the lower unit $(8.3 \%)$ than in the upper one $(7.3 \%)$. Palaeocarpological aspects analysed below impress a typical correlation between palynological and carpological analyses. In addition, the palaeobotanical data support the above-mentioned division, revealing that peat-forming vegetation consisted mainly of mixed forest type of vegetation for the lower unit and reedmoor and open water in the upper. Peat accumulated in a wet forest swamp under telmatic to limno-telmatic conditions and increased inorganic influx. Clay minerals prevail in all the samples with illite-muscovite being the dominant phase, kaolinite and chlorite the next. No smectite was found. The combination of mineralogical composition and the plant communities then growing in the studied area, hold up the hypothesis of humid and warm climatic conditions during the Achlada peat accumulation.

\section{Acknowledgments}

The authors would like to give special thanks to D. Tsiakalos for his staunch support during the laboratory work. Many thanks are also dedicated to W. Ricken and N. Tougiannidis from the Institute of Geology and Mineralogy at the University of Cologne as well as to W. Riegel from the University of Göttingen. Additionally, the authors are grateful to I. Sýkorová, S. Opluštil as well as the third reviewer for valuable comments and suggestions. Finally, many thanks are given to the Greek State Scholarships Foundation (S.S.F) for financial support.

\section{References}

AMERICAN SOCIETY FOR TESTING AND MATERIALS, ASTM D 2797 1990. Preparing coal samples for microscopical analysis by reflected light. 1990 Annual Book of ASTM Standards, Part 26, Gaseous Fuels: Coal and Coke. ASTM, Philadelphia, PA, 270-273.

ANTONIADIS, P. \& GREGOR, H.-J. 1996. Zum Fossilinhalt der Braunkohlen Lagerstätte Amynteon bei Kozani in NW-Griechenland. Documenta naturae 105(2), 1-16.

Antoniadis, P., Vlachou, A., Abatzi, S.M., Khanaga, P. \& RIEGEL, W. 2001. Preliminary coal petrographic study of the Achlada lignite deposit in the Florina domain. Proceedings of $9^{\text {th }}$ International Congress (Athens, September 2001). Bulletin of the Geological Society of Greece 34(3), 1185-1194 (in Greek).

Asikainen, C.A., Francus, P. \& Brigham-Grette, J. 2007. Sedimentology, clay mineralogy and grain-size as indicators of $65 \mathrm{ka}$ of climate change from El'gygytgyn Crater Lake, Northeastern Siberia. Journal of Paleolimnology 37, 105-122. DOI 10.1007/s10933-006-9026-5

BALI, E. 2005. Rehabilitation of Anargiri opencast mine at Florina area. 175 pp. BSc. dissertation, National Technical University of Athens, Greece.
BLACHOU, A. 1999. Geological and ore deposits study of Achlada lignite deposits in Florina basin, with emphasis on coal-petrography. 143 pp. BSc. dissertation, National Technical University of Athens, Greece.

BRUNN, J.H. 1956. Contribution à l'étude géologique du Pinde septentrional et d'une partie de la Macédoine occidentale. Annales géologiques des pays helléniques 7, 1-413.

COLlinson, M.E. \& SCOTT, A.C. 1987. Implications of vegetational change through the geological record on models for coal-forming environments, 67-85. In SCOTT, A.C. (ed.) Coal and coal-bearing strata: Recent advances. Special Publication of the Geological Society of London 32.

DansgaArd, W., Johnsen, S.J., Clausen, H.B., DAHL-JenSEN, D., GundeSTRUP, N., HAMMER, C.U. \& OESCHGER, H. 1984. North Atlantic climatic oscillations revealed by deep Greenland ice cores, 288-298. In HANSEN, J.E. \& TAKAHASHI, T. (eds) Climate processes and climate sensitivity, Geophysical Monograph 29. American Geophysical Union, Washington.

DENG, Y., WhITE, N. \& DiXON, J. 2002. Effect of structual stress on the intercalation rate of kaolinite. Journal of Colloid and Interface Science 250, 379-393. DOI 10.1006/jcis.2001.8208

DIESSEL, C.F.K. 1986. On the correlation between coal facies and depositional environments, 19-22. Proceeding of the $20^{\text {th }}$ Newcastle symposium on "Advances in the Study of the Sydney Basin”, Publication 246. Department of Geology, University of Newcastle, Australia.

DIESSEL, C.F.K. 1992. Coal-bearing depositional systems. 721 pp. Springer-Verlag, Berlin.

FLORES, D. 2002. Organic facies and depositional palaeoenvironment of lignites from Rio Maior Basin (Portugal). International Journal of Coal Geology 48, 181-195.

DOI 10.1016/S0166-5162(01)00057-X

GeOrgakopoulos, A. \& VAlceva, S. 2000. Petrographic characteristics of Neogene lignites from the Ptolemais and Servia basins, Northern Greece. Energy Sources 22, 587-602. DO] 10.1080/00908310050045546

GILLER, K.E. \& WHEELER, B.D. 1986. Peat and water chemistry of a flood-plain fen in Broadland, Norfolk, UK. Freshwater Biology 16, 99-114.

DOI 10.1111/j.1365-2427.1986.tb00951.x

ILIA, I. 2007. Clayey deposits of lignite-bearing Neogene basins in Thessaly and W. Macedonia and their application as absorption materials. 95 pp. Master thesis, National and Kapodistrian University of Athens, Greece.

INTERNATIONAL COMMITTEE FOR COAL PETROLOGY (ICCP) 1963. International Handbook of Coal Petrography, $2^{\text {nd }}$ edition. Centre National de la Recherche Scientifique, Paris, France.

INTERNATIONAL COMMITTEE FOR COAL PETROLOGY (ICCP) 1971. International Handbook of Coal Petrography, $I^{\text {st }}$ supplement to $2^{\text {nd }}$ edition. Centre National de la Recherche Scientifique, Paris, France.

INTERNATIONAL COMMITTEE FOR COAL PETROLOGY (ICCP) 1993. International Handbook of Coal Petrography, $3^{\text {rd }}$ supplement to $2^{\text {nd }}$ edition. Centre National de la Recherche Scientifique, Paris, France. 
INTERNATIONAL COMMITTEE FOR COAL AND ORGANIC PETROLOGY (ICCP) 2001. The new inertinite classification (ICCP System 1994). Fuel 80, 459-471.

IOAKIM, C. 1984. Analyse palynologique des dépôts lacustres du Pliocène de Ptolemais (Grèce septentrionale): un élément nouveau dans la reconstitution de l'histoire paléoclimatique des régions méditerranéennes orientales. Paléobiologie continentale 14(2), 315-332.

IORDANIDIS, A. \& GEORGAKOPOUlOS, A. 2003. Pliocene lignites from Apofysis mine, Amznteo basin, Northwestern Greece: petrographical characteristics and depositional environment. International Journal of Coal Geology 54, 57-68. DO1 10.1016/S0166-5162(03)00019-3

JAARSVELD, J. VAN, DEVENTER, J. VAN \& LUKEY, G. 2002. The effect of composition and termperature on the properties of fly ash- and kaolinite-based geopolymers. Chemical Engineering Journal 89(1-3), 63-73. DOI $10.1016 / \mathrm{S} 1385-8947(02) 00025-6$

Jensen, D., BODduM, J., TJELl, J. \& Christensen, T. 2002. The solubility of rhodochrosite $\left(\mathrm{MnCO}_{3}\right)$ and siderite $\left(\mathrm{FeCO}_{3}\right)$ in anaerobic aquatic environments. Applied Geochemistry 17, 503-511. DOI 10.1016/S0883-2927(01)00118-4

KAISER, H. \& ASHRAF, R. 1974. Gewinnung und Präparation fossiler Sporen und Pollen sowie anderer Palynomorphae unter besonderer Betonung der Siebmethode. Geologisches Jahrbuch A 25, 85-114.

KAlaitZiDis, S., BouzinOs, A. \& Christanis, K. 1998. The depositional palaeoenvironment of the Upper Xylitic Horizon of the Ptolemais lignite deposit. Proceedings of the $8^{\text {th }}$ International Congress of the Geological Society of Greece (Patras, 27.-29.5.1998), Bulletin of the Geological Society of Greece 32(2), 289-297 (in Greek).

Kalaitzidis, S., Bouzinos, A. \& Christanis, K. 2000. The lignite-forming palaeoenvironment before and after the volcanic tephra deposition in the Ptolemais basin, Hellas. Mineral Wealth 115, 29-42 (in Greek).

Kalaitzidis, S., Bouzinos, A., Papazisimou, S. \& ChrisTANIS, K. 2004. A short-term establishment of forest fen habitat during Pliocene lignite formation in the Ptolemais Basin, NW Macedonia Greece. International Journal of Coal Geology 57, 243-263. DOI 10.1016/j.coal.2003.12.002

Kalaitzidis, S., PAPAZISIMOU, S. \& Christanis, K. 2001. Forming conditions of the Graikas lignite, Northern Peloponnese. Proceedings of the $9^{\text {th }}$ International Congress of the Geological Society of Greece (Athens, 26.-28.9.2001), Bulletin of the Geological Society of Greece 34(3), 1195-1204 (in Greek).

KALAitZiDis, S., PAPAZISIMOU, S., GiAnNOUli, A., BouZINOS, A. \& CHRISTANIS, K. 2003. Preliminary comparative analyses of two Greek leonardites. Fuel 82, 859-861. DOI 10.1016/S0016-2361(02)00368-X

Kalkreuth, W., Kotis, T., PAPAnicolaou, C. \& KokkinaKIS, P. 1991. The geology and coal petrology of a Miocene lignite profile at Meliadi Mine, Katerini, Greece. International Journal of Coal Geology 17, 51-67. DOI $10.1016 / 0166-5162(91) 90004-3$
KAOURAS, G. 1989. Kohlepetrographische, palynologische und sedimentologische Untersuchungen der pliozänen Braunkohle von Kariochori bei Ptolemais/NW-Griechenland. 220 pp. Ph.D. thesis, University of Göttingen, Germany.

KloOsterboer-VAN Hoeve, M.L. 2000. Cyclic changes in the late Neogene vegetation of northern Greece, a palynological study. 131 pp. Ph.D. thesis, University Utrecht, Netherlands. LPP Contribution Series 12.

Koufos, G.D. 1982. Hipparion crassum Gervais, 1859 from the lignites of Ptolemais (Macedonia, Greece). Proceedings. Koninklijke nederlandse akademie van Wetenschappen, Series B 85, 229-239.

KoukouZaS, C. \& KoukouZAS, N. 1995. Coals from Greece: distribution, quality and reserves, 171-180. In WHATELEY, M.K.G. \& SPEARS, D.A. (eds) European Coal Geology. Special Publication of the Geological Society of London 82.

Kovar-Eder, J., KVAČEK, Z. \& MELler, B. 2001. Comparing Early to Middle Miocene floras and probable vegetation types of Oberdorf N Voitsberg (Austria), Bohemia (Czech Republic) and Wackersdorf (Germany). Review of Palaeobotany and Palynology 114, 83-125.

DOI $10.1016 / \mathrm{S} 0034-6667(00) 00070-1$

Kuder, T., Kruge, M.A., ShEARER, J.C. \& Miller, S.L. 1998. Environmental and botanical controls on peatification-a comparative study of two New Zealand restiad bogs using Py-GC/MS, petrography and fungal analysis. International Journal of Coal Geology 37, 3-27.

LOH, H. 1992. Die Genese und Fasies der quatertären Torf Lagerstätte von Agras (Griechish - Mazedonien) als Hintergrund der Braunkohlen - Mazeral - und Lithotypen-Bildung. 61 pp. Ph.D. thesis, Georg August Universität, Göttingen, Germany. DOI 10.1016/S0166-5162(98)00022-6

MADEJOVA, J. 2002. FTIR techniques in clay mineral studies. $V i$ brational Spectroscopy 944, 1-10.

MARKIC, M. \& SACHSENHOFER, R.F. 1997. Petrographic composition and depositional environments of the Pliocene Velenje lignite seam (Slovenia). International Journal of Coal Geology 33, 229-254. DOI 10.1016/S0166-5162(96)00043-2

Mavridou, E., Antoniadis, P., Khanaqa, P., Riegel, W. \& GENTZIS, T. 2003. Paleoenvironmental interpretation of the Amynteon-Ptolemaida lignite deposit in northern Greece based on its petrographic composition. International Journal of Coal Geology 56, 253-268.

DOI 10.1016/S0166-5162(03)00115-0

MCCABE, P. 1984. Depositional environments of coal and coalbearing strata, 13-42. In RAHMANI, R.A. \& FLORES, R.M. (eds) Sedimentology of coal and coal-bearing sequences. Special Publication of International Association of Sedimentologists 7. Blackwell, Oxford.

MiLANKOVITCH, M. 1941. Kanon der Erdbestrahlung und Seine Anwendung auf das Eiszeitenproblem. 633 pp. Serbian Academy of Sciences, Special Publication 133, Belgrade.

Moore, T.A. \& SHEARER, J.C. 2003. Peat/coal type and depositional environment - are they related? International Journal of Coal Geology 56, 233-252. DOI 10.1016/S0166-5162(03)00114-9 
MoUnTRAKIS, D.M. 1983. Structural geology of the North Pelagonian zone s.1. and geotectonic evolution of the internal Hellenides. 283 pp. Unpublished Habilitation thesis, University of Thessaloniki, Greece (in Greek).

MUKHOPADHYAY, P.K. 1989. Organic petrography and organic geochemistry of Texas Tertiary coals in relation to depositional environment and hydrocarbon generation, 1-118. Report of Investigation 188, Bureau of Economic Geology, The University of Texas, Austin.

NICKEL, B. 1987. Palynologische Untersuchungen an der Braunkohle von Megalopolis im Tagebau Thoknia (Peloponnes). 73 pp. Unpublished thesis, Vol. 2, Göttingen.

Oikonomopoulos, I., PERAKi, T., KAOURAS, G. \& ANTONIADIS, P. 2007. Mineralogical study of inorganic intercalated seams at Achlada lignite deposits (NW Greece). Bulletin of the Geological Society of Greece 40(2), 906-917.

Papanicolaou, C., Dehmer, J. \& Fowler, M. 2000. Petrological and organic geochemical characteristics of coal samples from Florina, Lava, Moschopotamos and Kalavryta coal fields, Greece. International Journal of Coal Geology 44, 267-292. DOI 10.1016/S0166-5162(00)00014-8

PAPAZISIMOU, S. 2002. Formation and evolution of coastal lignite seams in western Peloponnese. Ph.D. thesis, Department of Geology, University of Patras, Greece.

PAVLIDES, S.B. \& MounTRAKIS, D.M. 1987. Extensional tectonics of north-western Macedonia, Greece, since the late Miocene. Journal of Structural Geology 9, 385-392. DOI 10.1016/0191-8141(87)90115-5

PUBLIC POWER CORPORATION 1999. Department of Lignite Research in Ptolemais-Florina region. PPC archive.

RICH, F.J., KURN, D. \& DAVIS, T.D. 1982. The palaeoecological significance of Ovoidites. Palynology 6, 19-28.

RIEGEL, W. 1965. Palynology of environments of peat formation in south-western Florida. 189 pp. Ph.D. thesis, Pennsylvania State University, USA.

Riegel, W., KAOURAS, G. \& VelitZelos, E. 1995. Ecological aspects of coal formation in Neogene basins of Greece. Annales géologiques des pays helléniques 36, 649-661.

RIEGEL, W., WeHMEYER, D., MEINKE, K., SCHWARZ, G., APOSTOLIKAS, A. \& Velitzelos, E. 1989. Succession of depositional environments in the Neogene basin at Aliveri, Evia (Greece). Palaeogeography, Palaeoclimatology, Palaeoecology 70(1-3), 261-273. DOI 10.1016/0031-0182(89)90095-3

SAKOFARA, V. \& MiCHAILIDIS, K. 1997. The geology and coal petrology of a Pleistocene lignite profile at Horemi mine, Megalopolis basin, Peloponnese (southern Greece). International Journal of Coal Geology 33, 71-91.
SCOTT, A.C. 2002. Coal petrology and the origin of coal macerals: a way ahead? International Journal of Coal Geology 50, 119-134. DO1 10.1016/S0166-5162(02)00116-7

SHEARER, J.C., MoORE, T.A. \& DEMCHUK, T.D. 1995. Delineation of the distinctive nature of Tertiary coal beds. International Journal of Coal Geology 28, 71-98. DOI 10.1016/0166-5162(95)00014-3

STACH, E., MACKOWSKY, M., TEICHMÜLler, M., TAYLOR, G., Chandra, D. \& TeICHMÜller, R. 1982. Stach's Textbook of Coal Petrology. 535 pp. Gebrüder Borntraeger, Berlin.

STACHURA, E. \& RATAJCZAK, T. 2004. The origin of pyrite in Miocene lignite from "Belchatów" deposit. Mineralogical Society of Poland, Special Papers 24, 361-364.

SÝKOROVÁ, I., PICKEL, W., CHRISTANIS, K., WOLF, M., TAYLOR, G.H. \& FLORES, D. 2005. Classification of huminite-ICCP System 1994. International Journal of Coal Geology 62, 85-106. DOI 10.1016/j.coal.2004.06.006

TAYLOR, G.H., TEICHMÜLlER, M., DAVIS, A., DIESSEL, C.F.K., LitTKe, R. \& ROBERT, P. 1998. Organic Petrology. 704 pp. Gebrüder Borntraeger, Berlin \& Stuttgart.

TEICHMÜLlER, M., LITTKE, R. \& TAYLOR, G.H. 1998. The origin of organic matter in sedimentary rocks, 704. In TAYLOR, G.H., TEICHMÜLleR, M., DAVIS, A., Diessel, C.F.K., LITTKE, R. \& RoBert, P. (eds) Organic Petrology. 704 pp. Gebrüder Borntraeger, Berlin.

ȚiClEANU, N. \& DiACONIȚA, D. 1997. The main coal facies and lithotypes of the Pliocene coal basin Oltenia, Romania, 131-139. In GAYER, R.A. \& PEŠEK, J. (eds) European Coal Geology and Technology. Special Publication of the Geological Society of London 125.

Velitzelos, E. \& PETRESCU, I. 1981. Rare plant fossils from the Neogene ligniferous basin of Vegora. Annales géologiques des pays helléniques 30, 767-777.

WEERD, A. VAN DE 1979. Early Ruscinian rodents and lagomorphs (Mammalia) from the lignites near Ptolemais (Macedonia, Greece). Proceedings. Koninklijke nederlandse akademie van Wetenschappen, Series B 82, 127-170.

ZdRAVKov, A., Kostova, I., SACHSEnHOFER, R.F. \& KoRTENSKI, J. 2006. Reconstruction of paleoenvironment during coal deposition in the Neogene Karlovo graben. International Journal of Coal Geology 67, 79-94. DOI 10.1016/j.coal.2005.09.005

ZEPPOS, I., TSOUfLIDOU, S. \& LiAKOURA, K. 1993. Preliminary report for the exploitation of lignite (xylitic) deposits at Eastern margins of Florina's sub-basin. Public Power Corporation D.L.O - D.A.O, Athens (in Greek). 